\title{
Conflict Resolution in distance education
}

\author{
Ernst Ralf Hintz \\ University of South Australia
}

In September 1989, the Centre for Evening and External Studies at Macquarie University began a project to design, produce and offer Australia's first comprehensive unit in Conflict Resolution Studies. The aim of the project was threefold: (1) to assist the School of History, Philosophy and Politics in developing an exciting new area of study; (2) to provide external and internal students with an independent learning package; and (3) to evaluate as a case study the effectiveness of the instructional design and to assess student response to material in the distance education mode.

\section{A new area of study}

Conflict Resolution is "essentially a practical discipline" (Tillett, 1990). Using an interdisciplinary approach it seeks to deal with conflict positively and creatively. The underlying assumption is that most conflict need not be destructive and all parties can benefit from resolution. The basic principles are useful and attractive to students because they learn to apply them in simulated situations that encompass both the personal and professional spheres, and range from management and industrial relations to counselling and environmental issues. The principles further apply to conflicts regardless of whether their scope is intra/inter-personal, intergroup, or inter-national.

As a new and highly applied discipline the study of Conflict Resolution also involves students in both the search for innovative solutions and the practice of resolving (simulated) conflict. This problem-solving aspect proves especially attractive as students are encouraged to view themselves as actual participants in a heuristic venture. By thinking about and discovering resolutions to different types of conflict, students can effect a contribution to research in a field very much in its formative phase as an academic discipline. 


\section{Design perspectives in open learning}

The development of the Conflict Resolution Unit as an independent learning package anticipates the move in Australian distance education toward open learning: "It is a key concept in open learning that the focus is on the student's learning, not on the instructor's teaching. Therefore the 'syllabus' is more likely to consist of a set of learning materials than a lecture program" (Johnson, 1990). The unit offers five modules as independent, yet interrelated sets of learning materials (Rogers, 19875). The learner-centred modules proceed from the theory to practice, whereby the student works through types and issues of conflict resolution. Modules also summarise and synthesise by offering comparative approaches for the application of general principles.

Several instructional design theories contribute to the strategies used in the unit. These are chiefly the Gagne-Briggs theory to sequence the events of instruction (Petry, Mouton, Reigeluth, 1987), Component Display Theory for prescribing strategy components (Merrill, 1987) and the modified use of synthesisers for review purposes (Reigeluth, 1987). The overall design blends aspects of the above theories to create an independent learning package tailored to meet the needs of the distance learner.

The entire unit comprises a "learning hierarchy" in which the student proceeds from the theory and principles of conflict resolution to its practice. The end-of-unit objective is to improve the student's "capabilities of creative problem-solving". This desired learning outcome determines the sequencing of the modules.

\section{The Modules: learning strategy at the macro-level}

Module One involves the student in defining conflict and subsequently Conflict Resolution, then in a discourse on major theories. The Second Module moves directly to the practice of Conflict Resolution; this includes analysing conflict and planning resolution, role-playing and game theory. The subsequent three modules explore practice related aspects such as types of conflict; basic issues; and principles of Conflict Resolution.

The practice-solving thrust of the sequencing also extends to the lectures (= module sections) which highlight, for instance, conflict analysis by identifying types such as inter-personal and relationship conflict or employment and industrial conflict. Tape cassettes accompanying the modules expand the individual lectures and provide students with supplementary discussions of module topics as well as the human factor of the instructor's voice. 
Thus the sequence of modules begins a process of gradual student participation in problem-solving activities. These activities in the independent learning package are based on specific performance objectives in the lectures themselves. However, the "text" of the lectures comprises not only words, but illustrations, flowcharts and tapes. This broader definition of "text" includes diverse opportunities for creative thinking. As such, the lectures promote an "interactive discourse" with students in achieving performance objectives (Juler, 1990). This active rather than passive approach to the instructional "text" furthers learner independence as both a stimulus and preparation for problem-solving. The high level of student involvement with flexible instructional texts proves useful in learning Conflict Resolution as an innovative hands-on activity.

Like the Gagne-Briggs theory, Merrill's Component Display Theory prescribes methods of instruction according to a given classification of learning outcomes (Gagne-Briggs, 1979; Merrill, 1987). However, while the Gagne-Briggs theory offers a hierarchical framework for the macrostrategy of the entire unit, Merrill's theory (CDT) proffers microstrategy for the individual lectures (= module sections).

\section{The lectures: learning strategy at the micro-level}

The design of Lecture One - and of all subsequent lectures in the independent learning package - derives in part from applying CDT to the specific needs of learning Conflict Resolution. The main learning outcomes in the first lecture of Module One are the description and definition of conflict, and an attendant working definition of conflict resolution. On the basis of a modified version of the Performance Content Matrix (Merrill, 1987), student learning outcomes are classified as in Figure 1.

Lecture One comprises four exercises based on the interplay of expository and inquisitory presentation modes (Merrill, 1987) as a means of "instructional transfer" (Brooks and Dansereau, 1987). These exercises emphasise the learner-centred orientation and the necessity for each student to transfer learning from his or her own experience to the practice of Conflict Resolution. Accordingly, the first exercise guides the student from a given generality and instance of conflict to distinguishing between conflict, problem, and dispute.

The second exercise affects a transfer: "identify an example of a problem, dispute and a conflict from your own personal or professional experience. Also identify a problem or dispute which may have been indicative of an underlying conflict." Thus the transfer immediately aims to extend the concept by finding events with shared characteristics. After the introduction of new working definitions such as intra-personal conflict, inter-personal conflict, intra-group, etc., another transfer occurs in the 
Figure 1: Learning outcomes for Lecture 1 of Module One:

\begin{tabular}{|c|c|c|c|c|}
\hline & Exencise 1 & Exercise 2 & Exencise 3 & Exercise 4 \\
\hline $\begin{array}{l}\text { FIND "a new } \\
\text { generality" }\end{array}$ & $\begin{array}{l}\text { Derive new } \\
\text { working } \\
\text { definition of } \\
\text { conflict }\end{array}$ & $\begin{array}{l}\text { Identify } \\
\text { problems or } \\
\text { disputes } \\
\text { indicative of } \\
\text { an underlying } \\
\text { conflict }\end{array}$ & & $\begin{array}{l}\text { Think of three } \\
\text { symptoms as } \\
\text { manifestations } \\
\text { of conflict from } \\
\text { the various } \\
\text { aress }\end{array}$ \\
\hline $\begin{array}{l}\text { USE "applya } \\
\text { generality to a } \\
\text { specific case" }\end{array}$ & $\begin{array}{l}\text { Identify } \\
\text { differences } \\
\text { between } \\
\text { "problem", } \\
\text { "dispute" and } \\
\text { "conflict" }\end{array}$ & $\begin{array}{l}\text { give specific } \\
\text { cases from } \\
\text { personal } \\
\text { expenence }\end{array}$ & $\begin{array}{l}\text { give } \\
\text { examples of } \\
\text { intrajinter } \\
\text { personal, } \\
\text { intralinter } \\
\text { group etc } \\
\text { from personal } \\
\text { expenence }\end{array}$ & $\begin{array}{l}\text { identify } \\
\text { symptoms of } \\
\text { potential } \\
\text { conflict for the } \\
\text { given cases }\end{array}$ \\
\hline $\begin{array}{l}\text { REMEMEER } \\
\text { GENERALIT } \\
\text { "statement of a } \\
\text { definition, } \\
\text { pinciple } \\
\text { or the steps in } \\
\text { a procedure" }\end{array}$ & $\begin{array}{l}\text { given a } \\
\text { dictionary } \\
\text { definition of } \\
\text { conflict }\end{array}$ & $\begin{array}{l}\text { common and } \\
\text { differing } \\
\text { charactenstics } \\
\text { of "problem", } \\
\text { "dispute" and } \\
\text { "conflict" }\end{array}$ & $\begin{array}{l}\text { new working } \\
\text { definition of } \\
\text { the specific } \\
\text { areas of } \\
\text { conflict }\end{array}$ & $\begin{array}{l}\text { diagnostic } \\
\text { prescriptive } \\
\text { approach to } \\
\text { conflict } \\
\text { resolution: } \\
\text { "analyse } \\
\text { existing or } \\
\text { potential } \\
\text { conflicts, } \\
\text { diagnose } \\
\text { causes and } \\
\text { offer options } \\
\text { for resolution }\end{array}$ \\
\hline \multirow[t]{2}{*}{$\begin{array}{l}\text { FEMEMEER } \\
\text { INSTAHCE } \\
\text { "specific } \\
\text { illustrations" }\end{array}$} & $\begin{array}{l}\text { thesaunis } \\
\text { synonyms }\end{array}$ & examples & examples & $\begin{array}{l}\text { examples of } \\
\text { symptoms from } \\
\text { the vanious } \\
\text { conflict areas, } \\
\text { inter-personal } \\
\text { conflict, etc. }\end{array}$ \\
\hline & FACT & COHCEFT & FFINCIFLE & PFOCEDURE \\
\hline
\end{tabular}

third exercise: "It would be useful to set down examples from each of the given areas of conflict (whenever possible from your own experiences)." The final exercise asks the student to explore distinctions between various areas of conflict by discovering how conflict manifests itself. This activity provides a preliminary exercise in problem solving:

Consider ways in which conflict manifests itself: think of at least three examples of 'symptoms' which would, in different situations, alert you to the fact that conflict existed. Let the symptoms be manifestations from some of the various conflict areas. 
For example, in the area of inter-personal conflict you could note the following symptom: a parent shouts at a child for singing nursery rhymes in a supermarket. This could be as a manifestation of the parent's frustration in basing the child-parent relationship on the Victorian standard of 'a child should be seen and not heard.'

A discourse follows to explain simplistic models of conflict resolution and to contrast them with the idea of "creative conflict." Hence the lecture integrates learning activities in the exercises with a working definition of conflict and stresses the importance of innovative thinking.

\section{The workshop}

A three-day workshop on campus complemented the distance education mode. The students had the opportunity to put theories and principles of conflict resolution into practice through a series of simulated conflict situations. Workshop activities were organised to develop "cognitive strategy," one of the target categories of learned capabilities from Gagne and Briggs (1979). The goal was to increase the student's capacity to resolve conflict by providing problem-solving strategies which ranged from "identifying contradictions", and "breaking a problem up into parts" to "working backwards" from the proposed resolution" (Petry, Mouton, Reigeluth, 1987).The workshop also acted as a summariser and synthesiser to integrate materials from various modules at the macrostrategy level (Reigeluth, 1987). By having students practice the resolution of simulated conflicts under the guidance of the instructor in a group situation, students could experience the interrelation of theoretical concepts and practical procedures. Students also received immediate feedback on their practiced resolutions. Finally, the workshop gave distance students an opportunity to meet with their instructor and to discuss submitted assignments.

\section{The transfer of learning}

The design strategy further aims at setting up a "framework for instructional transfer" (Brooks and Dansereau, 1987). The unit encourages students to transfer skills and knowledge gained in their own areas of expertise and everyday lives to Conflict Resolution - an area conducive to transfer because of its the highly interdisciplinary character. The underlying model for the complex interactions in this transfer stems from the memory and learning theory of Gagne and White (1978), whereby the transfer of knowledge into memory occurs by way of four structures: (1) networks of propositions, (2) intellectual skills, (3) images, and (4) episodes. 
The "network of propositions" - in this case, the theoretical and operational principles of conflict resolution - contribute to a flexible, problem solving approach by sharpening intellectual skills (Gagne and Briggs, 1979). For example, one major proposition gives a working definition of conflict: "conflict exists when two or more parties perceive that their values or their needs are incompatible" (Tillett, 1990). Other propositions in turn form a network by defining types of conflict: underlying conflict (cause); manifest conflict (symptom), and displaced conflict (indirect or invisible conflict). By identifying various types, the student develops a range of "intellectual skills" for problem-solving - itself classified as the foremost of these skills (Gagne and Briggs, 1979). Next images and episodes help the visual and verbal transfer of knowledge to memory and aid retention. Newspaper comics as well as illustrations from James Thurber serve the unit as an image and episodal resource. Facilitating transfer throughout the design, they prove an effective mnemonic aid.

\section{Evaluation}

With instructional and layout design completed on schedule, the Centre for Evening and External Studies offered the new unit externally in First Semester 1990. Of the [43] students initially enrolled, more than three quarters [35] successfully completed the unit. Many of the students lived outside of the Sydney metropolitan area, some at a considerable distance. When we compare the number of distance learners enrolled from the country with those from the Sydney metropolitan area, we find the following division:

$$
\begin{array}{lll}
\text { Initial Enrolments } & \text { Non-metropolitan (21) } & \text { Metropolitan (22) } \\
\text { Final Completion Group } & \text { Non-metropolitan (18) } & \text { Metropolitan (17) }
\end{array}
$$

On the basis of the enrolment and completion figures irrespective of other constraints (full-time employment, family obligations, etc.), access to the unit for about half of students depended on the availability of distance education because of their distance from campus. Conversely, the high percentage of metropolitan students indicates a clear need for distance education apart from the traditional geographic consideration.

The attendance of the obligatory on-campus workshop proved to be no obstacle for the students, both metropolitan and non-metropolitan alike, due to efficient forward planning. The high level of completion indicates, on the one hand, the importance of good "student support services" (Paul, 1990) as provided through the Centre for Evening and External Studies, the workshop, and the availability of instructor for consultation by telephone. On the other, it attests to the successful interaction of students with the instructional materials. 
Student responses to the designed material and the organisation of the unit were overwhelmingly positive. The instructor, Dr. Greg Tillett, commented:

\begin{abstract}
The response to the package from students has been very enthusiastic. The external students completed their three-day on-campus practical program last week and expressed their praise for the materials in very strong terms. Many of them said that, having undertaken external courses over a number of years and at a number of institutions, this was the best designed and organised program they had seen. They all expressed the view that it was one of the few they had seen which was clearly designed specifically to meet the needs of external students, including those who lived considerable distances from libraries or tertiary institutions.
\end{abstract}

\title{
Conclusion
}

The Conflict Resolution External Studies package has proved to be a viable offering for distance education students. Its success is due in part to the emphasis placed on the "open learning" approach as learner-centred instruction. In addition, the interdisciplinary thrust of the unit encourages "instructional transfer" and offers a program with practical, flexible applications in current Australian society. The positive response of the students (whether metropolitan or non-metropolitan), the instructor, and interested organisations outside of the university indicate the need for more units of this type in the distance education mode.

\section{Notes}

Comments used with permission of Greg Tillett from a letter of April 27, 1990 to the Vice-Chancellor of Macquarie University.

\section{References}

Brooks, L. W. and Dansereau, D. F. (1987). Transfer of information: An instructional perspective. In S. M. Cormier \& J. D. Hagman (eds.), Transfer of Learning - Contemporary Research and Applications. New York: Academic Press, Inc, pp121-150.

Gagne, R. M. \& Briggs, L. J. (1979). Principles of Instructional Design. New York: Holt, Rinehart and Winston.

Gagne, R. M. \& White, R. T. (1978). Memory structures and learning outcomes. Review of Educational Research, 48, 178-222.

Johnson, R. (1990). Open Learning: Policy and Practice. Commissioned Report No. 4, National Board of Employment, Education and Training, p.14.

Juler, P. (1990). Promoting interaction: Maintaining independence: allowing the mixture. Open Learning, 5(2), June, 24-33. 
Merrill, D. M. (1987) . A lesson based on the component display theory. In C. M. Reigeluth (ed.), Instructional Theories in Action. Hillsdale, NJ: Lawrence Erlbaum Associates, pp201-244.

Petry, B., Mouton, H. \& Reigeluth, C. M. (1987). A Lesson based on the Gagne-Briggs theory of instruction. In C. M. Reigeluth (ed.), Instructional Theories in Action. Hillsdale, NJ: Lawrence Erlbaum Associates. pp11-44.

Reigeluth, C. M. (1987). Lesson blueprints based on the elaboration theory of instruction. In C. M. Reigeluth (ed.), Instructional Theories in Action. Hillsdale, NJ: Lawrence Erlbaum Associates. pp245-288.

Rogers, W. S. (1987). Adapting materials for alternative use In M. Thorpe \& Grugeon (eds.), Open Learning for Adults. London: Longman. p45.

Paul, R. (1990). Towards a new measure of success: Developing independent learners. Open Learning, 5(1), 31-37.

Tillett, G. (1990). Conflict Resolution. Macquarie University, Centre for Evening and External Studies.

Author: Dr. Ernst Ralf Hintz, School of Advanced Studies in Education, University of South Australia, Holbrooks Road, Underdale, SA, 5032, Australia.

Please cite as: Hintz, E. R. (1991). Conflict Resolution in distance education. Australian Journal of Educational Technology, 7(1), 23-30. http: / / www.ascilite.org.au/ajet/ajet7/hintz.html 